\title{
Impairment of Natural Killer Functions by Interleukin 6 Increases Lymphoblastoid Cell Tumorigenicity in Athymic Mice
}

Jerome Tanner and Giovanna Tosato

Laboratory of Immunology, Center for Biologics Evaluation and Research, Bethesda, Maryland 20892

\begin{abstract}
Expression of the human IL-6 gene in EBV-immortalized normal human B lymphocytes following retroviral-mediated transduction rendered these cells highly tumorigenic in athymic mice. The tumors were lymphomas composed of the originally inoculated human lymphoblastoid cells. Co-injection of IL-6 expressing EBV-immortalized cells with IL-6 nonexpressing control cells resulted in increased tumorigenicity of the IL-6 nonexpressing cells. The lymphoblastoid cells expressing IL-6 were indistinguishable from parental cell lines in morphology and in a variety of cell surface characteristics, and did not exhibit growth advantage over parental cell lines in vitro, such that increased tumorigenicity is unlikely to depend upon a direct oncogenic effect of IL-6 on the B cells. Rather, at high concentrations, IL-6 markedly inhibits human lymphoblastoid cell killing by IL-2-activated murine splenocytes in vitro, suggesting that IL-6-related tumorigenicity might depend upon IL-6 inhibiting cytotoxicity at the tumor site. Thus, production of IL-6 by tumor cells that results in natural killer cell dysfunctions illustrates a novel mechanism of tumor cell escape from immune surveillance. (J. Clin. Invest. 1991. 88:239-247.) Key words: cytokine $\bullet$ gene transfer $\bullet$ Epstein-Barr virus $\bullet$ lymphoma - cytotoxicity
\end{abstract}

\section{Introduction}

Malignancies of EBV-infected B cells such as X-linked lymphoproliferative disease (1), AIDS-associated lymphomas $(2,3)$, and post-transplant lymphomas (4) represent unique model systems for which a number of pathogenetic steps have been suggested $(5,6)$. In vitro, B lymphocytes can be immortalized by EBV into long-term cell lines (7). In vivo, B cells naturally infected with EBV are long-lived and subjected to immunoregulatory controls to prevent their expansion $(6,7)$. In the presence of severe immunodeficiency, EBV-infected B cells can proliferate in vivo, giving rise to polyclonal or oligoclonal malignancies.

IL-6, a multifunctional cytokine produced in monocytes, fibroblasts, and other cell types (for a review, see reference 8), has been implicated in the pathogenesis of several human cancers, including Kaposi sarcoma (9), cardiac myxoma (10), Castleman's disease (11), multiple myeloma $(12,13)$, nonHodgkin's B cell lymphomas (14), and B cell chronic lympho-

Address correspondence to Dr. Giovanna Tosato, Center for Biologics Evaluation and Research, Building 29, Room 501, Bethesda, MD 20892.

Received for publication 7 November 1990 and in revised form 18 January 1991

The Journal of Clinical Investigation, Inc.

Volume 88, July 1991, 239-247 cytic leukemia (15). Recently, IL-6 has been identified as an important factor in the establishment and maintenance of EBV-immortalized B cells $(16,17)$. These virally infected cells secrete low levels of IL-6 in the culture supernatant (18), express surface receptors for IL-6 (19), and can use this cytokine as an autocrine growth factor (18).

To explore a possible role of IL-6 in the multistep process of B cell tumorigenesis, we have stably expressed the human IL-6 gene into EBV-immortalized B cells and examined the ability of these cells to form tumors in athymic mice. Unlike in vitro studies that rely upon the contribution of a limited number of cell types, this in vivo approach allows one to register the participation of the diverse cell types that may be affected by IL- 6 and may contribute or prevent tumor formation. This is particularly relevant in the case of IL- 6 that is emerging as one of the most pleiotropic of cytokines with a broad range of biological activities (for a review, see reference 8). While parenteral administration of the cytokine together with EBV-immortalized cells has the potential of affecting all IL-6-responsive targets, this approach is compromised by the relatively short half-life of IL-6 (20), and the potential need to achieve sustained effective levels locally. Accordingly, we have used an alternative strategy of expressing the IL-6 gene in the EBV-immortalized cells. Using this approach, high concentrations of IL-6 may be achieved within the local environment during the entire tumor-immune effector cell interaction. The present experiments show that IL-6-expressing lymphoblastoid cell lines are highly tumorigenic in vivo, and this effect is likely due to IL-6-induced dysfunction of natural killer (NK) ${ }^{1}$ functions.

\section{Methods}

Plasmid construction. The nucleotide sequence containing the open reading frame for human IL-6 was isolated as the Hind III and Bam I $(0.67 \mathrm{~kb})$ fragment from the cDNA clone $\mathrm{p} \beta-2-22$ (21; a gift from $\mathrm{P}$. B. Sehgal, The Rockefeller University, New York, NY), followed by T4 polymerase repair, and blunt-end ligation of Bam HI linkers (Gibco Laboratories, Grand Island, NY). The insert was Bam HI restricted and inserted at the Bam HI site of the vector pZip-NEO-SV(x) $1(22,23)$. Proper orientation was verified by restriction endonuclease analysis.

Transfection and infection. Subconfluent PA317.3 cells (No. CRL9078; American Type Culture Collection, Rockville, MD) that contain the packaging-signal-defective AM-MLV amphotropic helper virus (24) were transfected with $10-20 \mu \mathrm{g}$ of linearized pZipNEOSV(x)1 or pZip-NEOSV(x)1-IL-6 plasmid DNA in 60-mm petri dishes using lipofection (Gibco Laboratories). After 48-72 h the cells were replated in culture medium consisting of DME (Gibco Laboratories) with 10\% FCS (Rehatuin; Intergen Co., Purchase, NY) and 600 $\mu \mathrm{g} / \mathrm{ml}$ of Geneticin (Gibco Laboratories). After a 3-wk incubation, neomycin-resistant colonies were picked and assayed for expression of IL-

1. Abbreviations used in this paper: LAK, lymphokine-activated killer; NK, natural killer. 
6, using the IL-6-dependent murine hybridoma cell line B9 (25; a gift of Dr. R. Nordan, National Institutes of Health, Bethesda, MD).

Culture supernatants of human IL-6-transfected PA317.3 cells producing the pZip-NEO-SV(x)1-IL-6 retroviruses were used to infect two EBV-induced lymphoblastoid cell lines, VDS-0 and TB. Neomycin-resistant VDS- 0 and TB cell clones were selected in RPMI-1640 medium (Gibco Laboratories) supplemented with 10\% FCS (Rehatuin), $2 \mathrm{mM}$ L-glutamine (Gibco Laboratories), and $1 \mathrm{mg} / \mathrm{ml}$ geneticin (Gibco Laboratories). Neomycin-resistant VDS- 0 and TB cell clones were assayed for IL-6 production using the IL-6-dependent cell line B9.

Radiolabeling and Immunoprecipitation. Lymphoblastoid cells $\left(10^{6} \mathrm{cells} / \mathrm{ml}\right.$, total volume $\left.2 \mathrm{ml}\right)$ were incubated for $18-24 \mathrm{~h}$ in methionine-free MEM (Gibco Laboratories) supplemented with $10 \%$ dialyzed FCS (Gibco Laboratories) and $200 \mu \mathrm{Ci} / \mathrm{ml}{ }^{35}$ S]methionine $(1055 \mathrm{Ci} /$ mmol; New England Nuclear, Boston, MA). Aliquots ( $1 \mathrm{ml}$ ) of cell-free culture supernatants that had been clarified by 30 min centrifugation $(13,000 \mathrm{~g})$ were incubated with a rabbit antiserum to human IL-6 (Genzyme Corp., Boston, MA) at a final dilution of 1:100. After a 2-h incubation at $4^{\circ} \mathrm{C}$, the samples were processed for immunoprecipitation as previously described (26), suspended in $50 \mu$ l gel sample buffer (0.125 M Tris, pH 6.8, 4\% SDS, $10 \%$ 2-mercaptoethanol, and $10 \%$ glycerol), boiled for $10 \mathrm{~min}$, centrifuged, and then electrophoresed through a $12.5 \%$ polyacrylamide gel containing $0.1 \%$ SDS (27). Gels were fixed for $30 \mathrm{~min}$ in $25 \%$ methanol and $10 \%$ glacial acetic acid, treated with Enlightening (New England Nuclear), dried, and exposed to Kodak XAR-2 film at $-80^{\circ} \mathrm{C}$.

Assay for IL-6 bioactivity. The murine hybridoma cell line B9 (a gift of Dr. R. Nordan, National Institutes of Health) was used in a standard assay for IL-6 bioactivity (25). $1 \mathrm{U}$ of IL-6 bioactivity in this assay is defined as the activity inducing half-maximal proliferation of B9 cells. An IL-6 concentration of $1 \mathrm{U} / \mathrm{ml}$ corresponds to $\sim 20 \mathrm{pg}$ of Escherichia coli-derived human IL-6 used throughout as a laboratory standard (a gift of Genetics Institute, Boston, MA) and to $5.5 \mathrm{U} / \mathrm{ml}$ of the interim NIH reference IL-6 standard (preparation 88/414).

Cell proliferation assay. Parental cell lines VDS-0 and TB, and IL6-transduced clones VDS-0 and TB were plated at 50-100,000 cells/ $\mathrm{ml}$ in triplicate flat-bottomed microtiter wells $(0.2 \mathrm{ml} /$ well; Costar, Cambridge, MA) in culture medium consisting of either Opti-MEM (Gibco Laboratories), or RPMI-1640 medium supplemented with 10\% heat-inactivated FCS and $2 \mathrm{mM}$ glutamine, and incubated at $37^{\circ} \mathrm{C}$ in a humidified atmosphere containing $5 \% \mathrm{CO}_{2}$. Cultures were pulsed with $\left[{ }^{3} \mathrm{H}\right]$ thymidine $(0.5 \mu \mathrm{Ci} /$ well $)$ during the final $4.5 \mathrm{~h}$ of a $3-\mathrm{d}$ culture. Results are expressed as mean $\mathrm{cpm} \pm \mathrm{SEM}$.

Anti-IL-6 antibodies and neutralization assays. A rabbit antiserum to highly purified natural murine IL-6 $(28)$ was purified with protein A-Sepharose (a gift of Dr. R. Nordan, National Institutes of Health). A mouse MAb to $E$. coli-derived human IL-6 (CLB IL-6/8, reference 29) was used after protein $G$ purification of hybridoma culture supernatant (a gift of L. A. Aarden, Central Laboratory of the Netherlands, Red Cross Blood Transfusion Service, Amsterdam, The Netherlands). Mouse IL-6 purified from culture supernatants of the murine macrophage P388D1 cell line (30) was a gift of Dr. R. Nordan, National Institutes of Health. Highly purified $E$. coli-derived recombinant human IL-6 was a gift of Genetics Institute.

Anti-mouse or anti-human IL- 6 antibody $(10 \mu \mathrm{g} / \mathrm{ml}$ and $5 \mu \mathrm{g} / \mathrm{ml}$, respectively) was incubated $\left(37^{\circ} \mathrm{C}\right.$ for $1 \mathrm{~h}$ ) with either IL-6 (mouse or human) or test culture supernatants at varying dilutions in flat-bottomed microtiter plates (final volume $0.1 \mathrm{ml}$ ). After incubation, B9 cells $\left(3 \times 10^{3}\right.$ cells in $\left.0.1 \mathrm{ml}\right)$ were added to each well. Culture medium consisted of RPMI-1640 (Gibco Laboratories) supplemented with 10\% FCS (Reheis) and $10^{-4} \mathrm{M}$ 2-mercaptoethanol. $\left[{ }^{3} \mathrm{H}\right]$ Thymidine incorporation was measured during the last $18 \mathrm{~h}$ of a $3-\mathrm{d}$ culture.

Animal studies. 4-6-wk-old female outbred $n u / n u$ mice (HarlanSprague-Dawley, Madison, WI) maintained in pathogen-limited conditions were used throughout for these experiments. Exponentially growing lymphoblastoid cell lines with a viability greater than $95 \%$ were injected ( $10^{7}$ cells in $0.2 \mathrm{ml}$ RPMI-1640 medium containing $10 \%$ FCS) subcutaneously in the right abdominal quadrant through a 25 - gauge needle on plastic 1-ml syringes. In some experiments, an IL-6 virus-infected cell line was co-injected subcutaneously with a control cell line $\left(5 \times 10^{6}\right.$ cells of each type in $\left.0.2 \mathrm{ml}\right)$, essentially as described (31). Animals injected with either cell line alone served as controls. All animals were observed every 2-3 d and tumor size was estimated in $\mathrm{mm}^{2}$ as the product of two-dimensional caliper measurements (longest perpendicular length and width).

Histology evaluation. Representative samples of tumor tissue were fixed in $10 \%$ neutral buffered-formalin (Media Kitchen, NIH, Bethesda, MD), blocked in paraffin, sectioned at $4 \mu \mathrm{M}$, and stained with hematoxylin and eosin.

Expression of cell surface determinants. Exponentially growing lymphoblastoid cell lines $\left(10^{7}\right.$ cells $/ \mathrm{ml}$ in PBS containing 5\% FCS) were incubated for $30 \mathrm{~min}$ at $4^{\circ} \mathrm{C}$ with control reagents and mouse MAbs. These included anti-CD23 (anti-Leu-20; Becton Dickinson \& Co., Mountain View, CA), anti-CD10 (J5, Calla; Coulter Electronics Inc., Hialeah, FL), anti-CD11a (CLB-CD11a; Janssen Biochimica Turnhoutseneg, Beerse, Belgium), anti-CD18 (CLB-CD18, Janssen Biochimica), anti-CD20 (anti-Leu-16, Becton Dickinson \& Co.), antitransferrin receptor (Becton Dickinson \& Co.), anti HLA-DR (Becton Dickinson \& Co.), and an anti-human Ig goat IgG antiserum specific for heavy and light chains (Cappel Laboratories, Malvern, PA). When appropriate, the cells were further incubated $\left(30 \mathrm{~min}\right.$ at $\left.4^{\circ} \mathrm{C}\right)$ with an affinity-purified, fluorescein-labeled, goat anti-mouse Ig reagent (Becton Dickinson \& Co.). After washing, the cells were analyzed on a FACScan (Becton Dickinson \& Co.). For each determination, $10^{4}$ cells were examined.

Histocompatibility typing for HLA-DR was performed by the microcytotoxicity assay, as described (32).

Generation of IL-2-activated killer cells and cytotoxicity assay. Splenocytes, obtained from normal outbred female nude mice, 4-8 wk old, and suspended in culture medium consisting of a 1:1 mixture of RPMI-1640 medium (Gibco Laboratories) and EHAA medium (enriched Eagle's medium, Biofluids Inc., Rockville, MD) supplemented with 10\% FCS (Reheis), 2 mM L-glutamine (Gibco Laboratories), $10^{-4} \mathrm{M}$ 2-mercaptoethanol (Gibco Laboratories), and $5 \mu \mathrm{g} / \mathrm{ml}$ gentamycin (Sigma Chemical Co., St. Louis, MO), were cultured at 2 $\times 10^{6}$ cells/ml in 24-well tissue culture plates (Linbro, Flow Laboratories, Inc., McLean, VA), $2 \mathrm{ml}$ per well, with either IL-2 $(500 \mathrm{U} / \mathrm{ml}$; a gift of Cetus Corp., Emeryville, CA), or Cos-7-derived IL-6 alone (31; 10 $10^{8} \mathrm{U} / \mathrm{ml}$ ) or a combination of IL-2 and IL-6. After a 3-d culture, splenocytes were harvested and washed twice in tissue culture medium. Then viable cells were counted and tested for cytotoxicity, as described (33). Lymphoblastoid cells (VDS-0 and TB) and murine T cell leukemia YAC-1 cells (ATCC T1B 160) were used as ${ }^{51} \mathrm{Cr}$-labeled target cells. The percent specific cytotoxicity was calculated as: $100 \times$ [(experimental release - spontaneous release)/(total release - spontaneous release)].

\section{Results}

Generation of lymphoblastoid cell lines expressing high level $I L-6$. Two lymphoblastoid cell lines obtained by EBV (B95-8) immortalization of normal peripheral blood B lymphocytes were selected for these studies. VDS- 0 is monoclonal and does not secrete immunoglobulin (34), while TB is polyclonal and secretes IgM, IgG, and IgA. Because EBV-immortalized B cells have been shown to express low levels of IL-6, we selected lines that most differed in the levels of endogenous IL-6 secreted (19).

Complementary DNA sequences spanning the entire human IL- 6 coding region were cloned into the retroviral vector depicted in Fig. 1 (top panel) $(22,23$ ). The plasmid pZip-NEOSV(x)-1-IL6 was transfected into the amphotropic retroviral packaging cell line PA317.3 (24), and stably transfected cells were selected as a source of IL-6-encoding virus. Virus-con- 

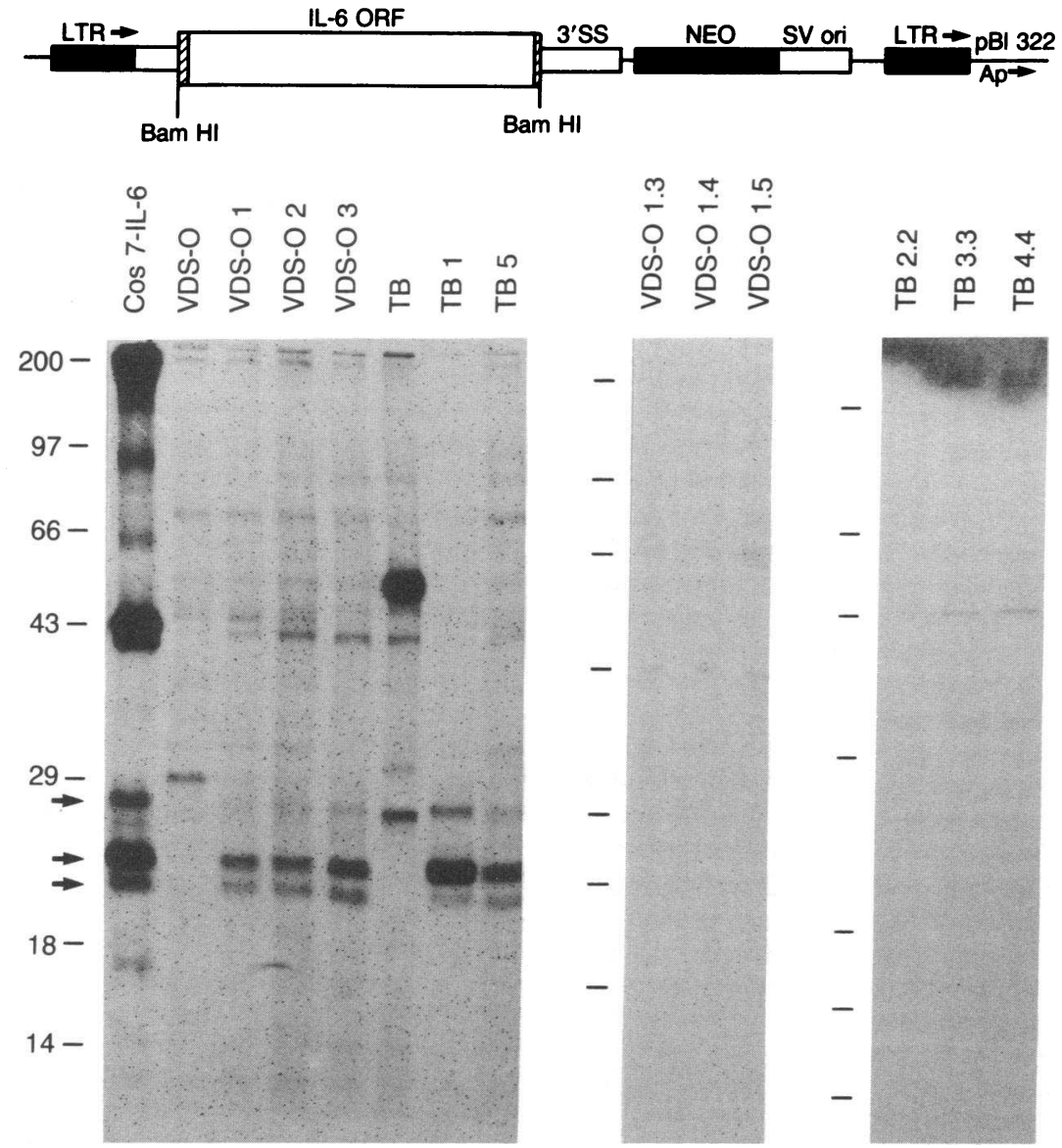
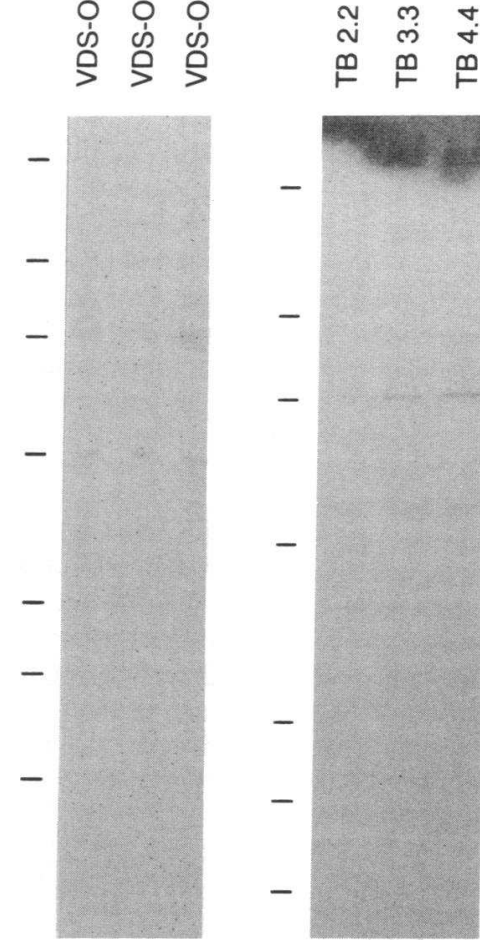

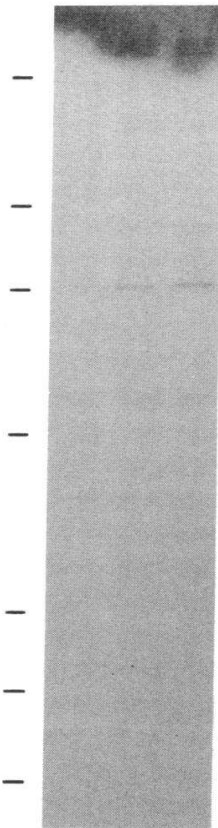

Figure 1. (Top) Diagrammatic representation of the IL-6 retroviral vector used for transfection of the retroviral packaging cell line PA317. The open reading frame (ORF) for human IL-6, isolated as a Hind III and Bam I fragment $(0.67 \mathrm{~kb})$ from the cDNA clone p- $\beta-2-22$ (21), was inserted at the Bam HI site of the vector pZip-NEO-SV(x)1 (22). (Bottom) Immunoprecipitable IL-6 detected in the culture supernatant of IL-6 virus-infected lymphoblastoid cells. ${ }^{35} \mathrm{~S}$-Labeled supernatants of either IL-6transfected Cos 7 cells (26) or the indicated lymphoblastoid cell lines were immunoprecipitated with an anti-human IL-6 rabbit serum. Immunoprecipitates were boiled and electrophoresed through a $12.5 \%$ polyacrylamide gel containing $0.1 \%$ SDS. Molecular weight standards are indicated at the left, and IL-6-related bands are indicated by arrows. taining supernatants from these cells were used to infect the VDS-0 and TB lymphoblastoid cell lines. Five neomycin-resistant, IL-6-producing cell clones were derived. As shown in Table I, while the two parent and vector control virus-infected (neomycin-resistance gene only) cell lines produced little or no IL-6, high level IL-6 secretion was observed in the IL-6 virusinfected cell lines. Immunoprecipitation of ${ }^{35} \mathrm{~S}$-labeled culture supernatants from the IL-6 virus-infected cell lines revealed the presence of material that reacted specifically with a polyclonal rabbit antiserum to human IL-6 and had electrophoretic mobility similar to that of IL-6 secreted by Cos 7 cells stably transfected with the human IL-6 gene (26) (Fig. 1, bottom panel). Under the conditions used, little or no immunoprecipitable IL-6 was detected in the supernatant of parental or virus control-infected cell lines (Fig. 1, bottom panel).

Tumorigenicity of high level IL-6 gene-expressing lymphoblastoid cell lines. EBV-immortalized lymphoblastoid cell lines are capable of long-term proliferation in tissue culture but generally fail to generate tumors when injected subcutaneously in athymic mice (35). As shown in Table II, parental and control virus-infected lymphoblastoid cells only rarely caused tumors in nude mice. Tumors developed in only 6 of 80 animals (7.5\%). In contrast, a high proportion (68\%) of the mice inoculated with the IL-6 virus-infected lymphoblastoid cell lines developed tumors in parallel experiments.

It should be noted (Table II) that the mean time of first tumor observation after inoculation was shorter for tumors induced by IL-6-expressing cell lines as opposed to the controls. For example, the rare tumors derived from injection of parental VDS-0 line and virus-control VDS- 01.5 line appeared

Table I. IL-6 Secretion in Lymphoblastoid Cell Lines

\begin{tabular}{llr}
\hline Cell line & \multicolumn{1}{c}{ Infecting virus } & IL-6 activity* \\
\hline & & $U / m l / 48 h$ \\
VDS-0 & None & 18.4 \\
VDS-0 1.3 & pZip-Neo-SV(x)1 & 2.8 \\
VDS-0 1.4 & pZip-Neo-SV(x)1 & 3.75 \\
VDS 1.5 & pZip-Neo-SV(x)1 & 3.2 \\
VDS-0 1 & pZip-Neo-SV(x)1-IL6 & 7,600 \\
VDS-0 2 & pZip-Neo-SV(x)1-IL6 & 826 \\
VDS-0 3 & pZip-Neo-SV(x)1-IL6 & 6750 \\
TB & None & 1.2 \\
TB 2.2 & pZip-Neo(x)1 & 0 \\
TB 3.3 & pZip-Neo(x)1 & 0 \\
TB 4.4 & pZip-Neo(x)1 & 0 \\
TB 1 & pZip-Neo-SV(x)1-IL6 & 40,562 \\
TB 5 & pZip-Neo-SV(x)1-IL6 & 16,750
\end{tabular}

* IL-6 activity was determined in a standard B9 culture assay and is expressed as units per milliliter of culture supernatant conditioned by $0.5 \times 10^{6}$ cells for $48 \mathrm{~h}$. Each data point corresponds to the mean of at least three determinations. 
Table II. Tumorigenicity of EBV-induced Lymphoblastoid Cell Lines in Athymic Mice

\begin{tabular}{lccc}
\hline \multicolumn{1}{c}{ Cell line } & $\begin{array}{c}\text { Tumor } \\
\text { incidence }\end{array}$ & $\begin{array}{c}\text { Mean time of } \\
\text { first observation }\end{array}$ & $\begin{array}{c}\text { Mean maximum } \\
\text { tumor size }\end{array}$ \\
\hline & & $d$ & $m^{2}$ \\
VDS-0 parent & $3 / 20$ & 32 & 218 \\
VDS-0 1.3 control & $0 / 7$ & - & - \\
VDS-0 1.4 control & $0 / 5$ & - & - \\
VDS-0 1.5 control & $1 / 8$ & 36 & 39 \\
VDS-0 1 IL-6 & $9 / 15$ & 21 & 42 \\
VDS-0 2 IL-6 & $12 / 15$ & 25 & 140 \\
VDS-0 3 IL-6 & $12 / 15$ & 23 & 168 \\
TB parent & $1 / 20$ & 48 & 103 \\
TB 2.2 control & $0 / 6$ & - & - \\
TB 3.3 control & $0 / 6$ & - & - \\
TB 4.4 control & $0 / 8$ & - & - \\
TB 1 IL-6 & $9 / 15$ & 33 & 27 \\
TB 5 IL-6 & $9 / 15$ & 27 & 45 \\
\hline
\end{tabular}

Outbred 4-6-wk-old female athymic mice were inoculated subcutaneously in one site with $10^{7}$ cells from the indicated cell lines and observed for $15 \mathrm{wk}$ for appearance of tumors $>5 \mathrm{~mm}^{2}$ in surface area. Data are compiled from four separate experiments. Tumor incidence is expressed as the fraction of mice with tumor per number of mice injected. Tumor size is expressed in surface area and reflects the product of two-dimensional caliper measurements.

at a mean of $33 \mathrm{~d}$ after inoculation and the more frequent tumors derived from injection of IL- 6 virus-infected VDS-0 lines appeared at a mean of $23 \mathrm{~d}$ after inoculation. In contrast, it should be noted that the mean maximum size reached by these tumors was similar in the two groups receiving either control $\left(120 \mathrm{~mm}^{2}\right)$ or IL-6 virus-infected lines $\left(84 \mathrm{~mm}^{2}\right)$.

Variation in IL-6 production among the different IL-6 virus-infected cell lines allows us to examine a possible correlation between the level of tumorigenicity and level of IL-6 produced by each line. The results of such analysis (Table III) show that neither tumor incidence nor time of first tumor occurrence, correlated directly with the levels of IL-6 produced by the IL-6 virus-infected lines. A similar conclusion was reached from experiments in which two IL-6-transfected cell lines, TB 1, a high IL-6 producer, and VDS-0 2, a low IL-6 producer, were injected subcutaneously at doses of 5, 2.5, and $1.25 \times 10^{6}$ cells per animal. The observation that IL- 6 virus-infected lines are significantly more tumorigenic than control lymphoblastoid lines together with the observation that the level of IL-6 secreted by these lines fails to correlate with tumorigenicity suggests that there might be a critical level of IL-6 sufficient for high level tumorigenicity.

Mixed tumor transplantation assays demonstrate cell transfer of IL-6-associated tumorigenicity. To test further whether IL-6 is responsible for increased tumorigenicity in EBV-immortalized cells, mixed tumor transplantation assays were performed (31). Initially, IL-6 virus-infected lines were inoculated subcutaneously in nude mice controlateral to control cells. Six of 10 mice injected with the IL-6 virus-infected line VDS-0 $3\left(10^{7}\right.$ cells/site) developed a tumor at the site of injection, but no animal developed a tumor at the controlateral site of injection of parent TB line $\left(10^{7}\right.$ cells/site). Since serum IL-6 levels were found to be within normal limits ( $\leq 5-10 \mathrm{U} /$ $\mathrm{ml}$ ) in tumor-bearing mice, we can draw no conclusions as to the systemic effects of IL-6 on B cell tumorigenicity.

In subsequent experiments, we simultaneously injected the IL-6 virus-infected lymphoblastoid cells together with control cells at the same site. When the parent TB cell line $\left(5 \times 10^{6}\right.$ cell $)$ was inoculated together with the IL- 6 virus-infected VDS- 01 line $\left(5 \times 10^{6}\right.$ cell $)$ in one subcutaneous site, 6 of 10 animals developed a tumor. Histocompatibility typing of the tumor cells within 2 wk from removal revealed four of these tumors to be composed of a mixed cell population, where both HLA-DR types of TB $(2,6)$ and VDS- $0(1,7)$ lines were represented. The two remaining tumors only expressed VDS-0-related histocompatibility HLA-DR antigens. We had previously determined that HLA-DR typing of purposely mixed VDS- 0 and TB cell lines can readily detect either HLA-DR type when at least $20 \%$ of the cells in the mixture derive from each of the cell lines. To quantitate further the cellular composition of the mixed tumors we took advantage of the observation that VDS- 0 and TB cell lines differ in surface Ig expression. As shown in Table IV, 38-62\% of the human HLA-DR-expressing tumor-derived cells were surface $\mathrm{Ig}^{-}$, demonstrating their derivation from the IL-6-producing VDS- 01 cell line. Most of the remaining human HLA-DR ${ }^{+}$cells were surface $\mathrm{Ig}^{+}$, demonstrating their derivation from the parental TB cell line. These findings demonstrate that tumorigenicity of IL-6 virus-infected lines can be transferred to other cells, and strongly suggests that IL-6 is responsible for these effects.

Natural history, histology, and IL-6 production by tumor cells. The IL-6 virus-infected lines displayed a characteristic pattern of tumorigenicity in nude mice. As shown above (Table II), all tumors arose within 2 mo of inoculation at the site of injection, and reached a maximum size of $240 \mathrm{~mm}^{2}$. Within 6-8 weeks from first appearance, some of these tumors, particularly the large tumors, underwent ulceration followed by total necrosis often associated with wasting and death of the animal; other tumors gradually decreased in size and eventually disappeared. In most cases, the tumors formed well-circumscribed spherical masses with at least some involvement of the overlying skin and underlying connective tissue and muscle, but local spread was limited and there was no evidence of metastasis.

Histologically (Fig. 2), rapidly growing tumors appeared as malignant lymphomas composed of sheets of cells without ar-

Table III. Relationship between Levels of IL-6 Production and Tumor Development

\begin{tabular}{llccc}
\hline Cell line & \multicolumn{1}{c}{ IL-6 level* } & $\begin{array}{c}\text { Tumor } \\
\text { incidence }\end{array}$ & $\begin{array}{c}\text { Mean time of } \\
\text { first observation }\end{array}$ & $\begin{array}{c}\text { Mean } \\
\text { maximum } \\
\text { size }^{4^{*}}\end{array}$ \\
\hline & \multicolumn{1}{c}{$U / m l$} & & $d$ & $\mathrm{~mm}^{2}$ \\
VDS-0 2 & Low (826) & $12 / 15$ & 35 & 140 \\
VDS-0 1 & Intermediate (7,600) & $9 / 15$ & 21 & 42 \\
TB 1 & High $(40,562)$ & $9 / 15$ & 33 & 27 \\
\hline
\end{tabular}

* IL-6 levels are expressed as B9 $\mathrm{U} / \mathrm{ml}$ supernatant conditioned by 0.5 $\times 10^{6}$ cells in $48 \mathrm{~h}$.

* Tumor incidence is expressed as number of animals with tumor per number of animals injected. Each animal received $10^{7}$ cells subcutaneously in one site.

${ }^{8}$ Tumor size is expressed in $\mathrm{mm}^{2}$ and reflects the product of two-dimensional caliper measurements. 
Table IV. Cells Surface $\mathrm{Ig}^{+}$or $\mathrm{Ig}^{-}$Expressing Human HLA-DR

\begin{tabular}{clc}
\hline & \multicolumn{2}{c}{$\begin{array}{c}\text { Human HLA-DR positive } \\
\text { cells }\end{array}$} \\
\cline { 2 - 3 } Mixed tumors* & $\mathrm{Ig}^{-}$ & $\mathrm{Ig}^{+}$ \\
\hline 1 & 38 & 58 \\
2 & 45 & 47 \\
3 & 47 & 41 \\
4 & 62 & 34 \\
\hline
\end{tabular}

* Single cell suspensions of tumors derived from subcutaneous injection of the IL-6-secreting VDS-O 1 line $\left(5 \times 10^{6}\right.$ cells) and the IL-6 nonsecreting TB cell line $\left(5 \times 10^{6}\right)$ were incubated at $4^{\circ} \mathrm{C}$ with a rhodamine-conjugated monoclonal antihuman HLA-DR reagent (Becton Dickinson \& Co.) and a fluorescein-conjugated polyclonal goat antiserum to human Ig (Cappel Laboratories).

${ }^{\ddagger}$ Percent cells surface $\mathrm{Ig}^{+}$or $\mathrm{Ig}^{-}$expressing human HLA-DR.

chitectural arrangement with little connective tissue and little inflammatory cells, except at the tumor margins. These consisted of lymphocytes and histiocytes. Most of the tumors were composed of medium-sized, uniform cells, reminiscent of Burkett's lymphoma (36). In some cases, there was a range in cell size with larger cells with vesicular nucleoli and prominent nucleoli.

Regressing tumors had prominent tumor necrosis, particularly toward the center of the tumor mass, and some infiltration with histiocytes both within and at the periphery of the tumor. It is important to note that three tumors from mice injected with control lines were indistinguishable microscopically from tumors observed in mice injected with IL-6 virusinfected lines.

With the goal of further defining their phenotype, tumors were fragmented into single cell suspensions and cultured in vitro. Two continuous cell lines were derived from separate mice injected with the parent VDS- 0 line (t VDS- 0 a and $b$ ); one from a mouse injected with the virus control line VDS-0 1.5 (t VDS-0 1.5); and five lines were derived each from separate mice injected with the IL-6 virus-infected lines VDS-0 1, 2 , and 3 , and TB 1 and 5 .

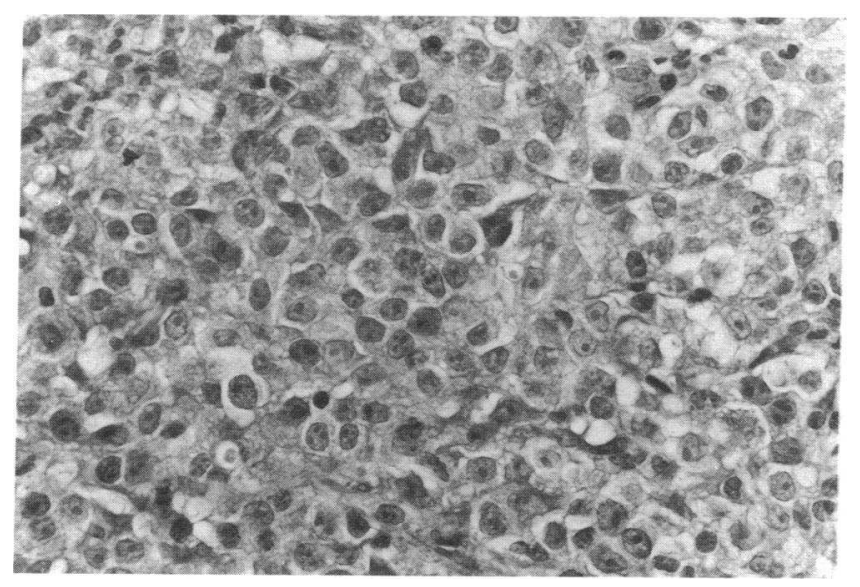

Table V. IL-6 Secretion by Tumor-derived Cells

\begin{tabular}{lcc}
\hline & \multicolumn{2}{c}{ IL-6 bioactivity* } \\
\cline { 2 - 3 } $\begin{array}{c}\text { Tumor-derived } \\
\text { cells/cell lines }\end{array}$ & $\begin{array}{c}\text { Immediately } \\
\text { after initiation } \\
\text { of culture }\end{array}$ & $\begin{array}{c}\text { After 12-15 } \\
\text { passages } \\
\text { in vitro }\end{array}$ \\
\hline \multicolumn{3}{c}{ U/ml/48 h } \\
tVDS-0 a & \multicolumn{3}{|}{} \\
tVDS-0 b & 29,050 & 980 \\
tVDS-0 1.4 & 51,187 & 6,224 \\
tVDS-0 1 & 15,160 & 528 \\
tVDS-0 2 & 9,587 & 6,620 \\
tVDS-0 3 & 15,500 & 1,743 \\
tTB 1 & 28,293 & 8,216 \\
tTB 5 & 57,887 & 49,600 \\
& 13,436 & 13,443 \\
\hline
\end{tabular}

* IL-6 bioactivity was determined in a standard B9 culture assay and is expressed as $U / \mathrm{ml}$ of culture supernatant conditioned with tumor-derived cells for $48 \mathrm{~h}$.

${ }^{\ddagger}$ After removal from the animal, tumors were fractionated into single cell suspensions and incubated at $2.0 \times 10^{6}$ cells $/ \mathrm{ml}$.

${ }^{8}$ Tumor-derived lymphoblastoid cell lines that had been passaged in culture 12-15 times were cultured at $0.5 \times 10^{6}$ cells $/ \mathrm{ml}$.

All these tumor-derived lines were indistinguishable microscopically from those originally injected in the animals and expressed the HLA type of VDS-0 or TB cell lines (not shown). In addition, all cell lines derived from tumor-bearing animals inoculated with virus-infected cell lines were neomycin-resistant, while the two cell lines from the parent VDS- 0 cell lines were neomycin-sensitive. Together, these data demonstrate that the tumors derive from in vivo growth of the injected human lymphoblastoid cells.

As shown in Table V, culture medium conditioned for $48 \mathrm{~h}$ with tumor-derived cells just removed from the animal contained high levels of IL- 6 bioactivity, generally higher than the IL-6 levels detected in the culture supernatant of the lines giving rise to the tumors (Table II). This difference could not be explained solely on the basis of cell culture input. In addition,

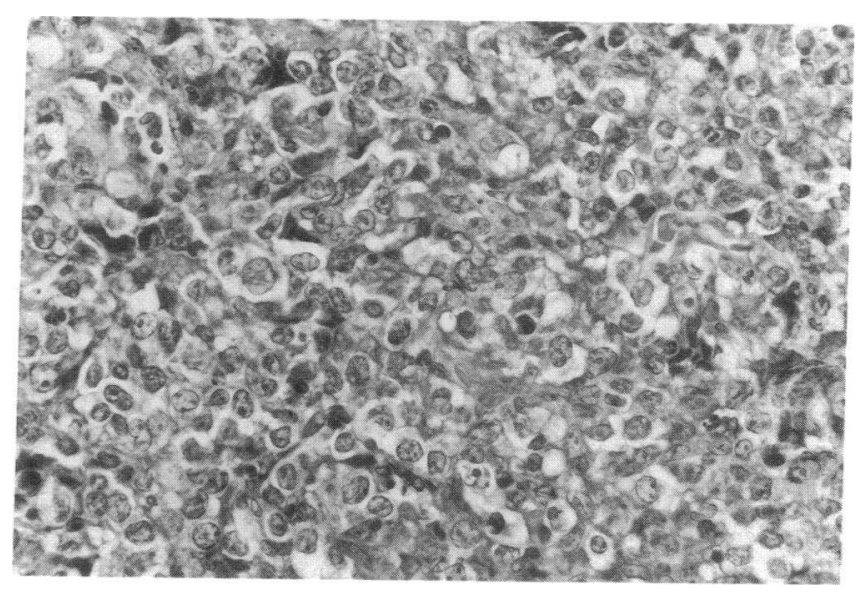

Figure 2. Sections of tumors from nude mice showing the histology of representative lymphoblastoid cell line-induced tumors. (Left) A lymphoma composed of medium-sized, uniform cells, reminiscent of Burkitt's lymphoma. Note the scarcity of connective tissue and of inflammatory cells. (Right) a lymphoma composed of cells of varying size, with larger cells displaying vesicular nuclei and prominent nucleoli. Both tumors derived from animals injected with the IL-6 virus-infected cell line VDS-0 3. Hematoxylin \& eosin stain, $\times 430$. 

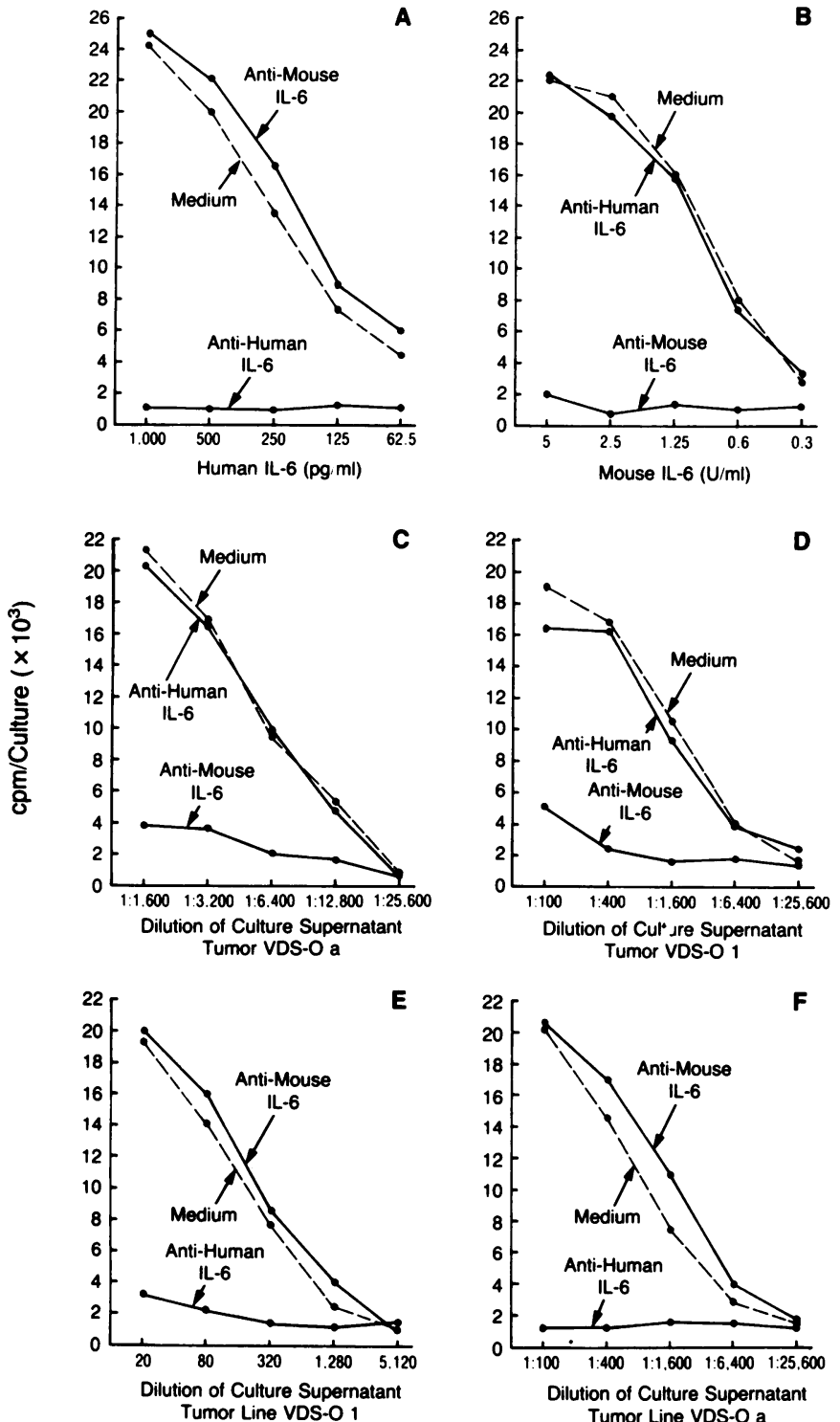

$\mathbf{E}$

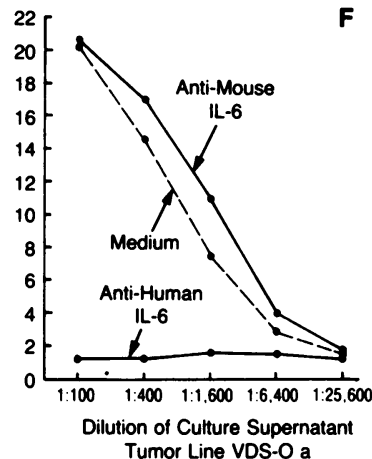

Figure 3. Detection of murine and human IL-6 in the culture supernatant of tumor-derived cells. Recombinant human $(A)$ or mouse $(B)$ IL-6 at the indicated concentration, was incubated for $1 \mathrm{~h}$ at $37^{\circ} \mathrm{C}$ with either medium or a MAb to human IL-6 $(5 \mu \mathrm{g} / \mathrm{ml})$ or with a rabbit IgG anti-mouse IL-6 $(10 \mu \mathrm{g} / \mathrm{ml})$ in a total volume of $0.1 \mathrm{ml}$. Culture medium conditioned for $48 \mathrm{~h}$ with cells from either fresh tumor VDS-0a $(C)$, or fresh tumor VDS-0 $1(D)$, or tumor-derived cell lines VDS-0a $(E)$, or VDS-0 $1(F)$ were incubated $\left(1 \mathrm{~h}, 37^{\circ} \mathrm{C}\right)$ at the indicated dilutions with either a MAb to human IL-6 $(5 \mu \mathrm{g} / \mathrm{ml})$ or rabbit IgG anti-mouse IL-6 $(10 \mu \mathrm{g} / \mathrm{ml})$; total culture volume, 0.1 $\mathrm{ml}$. After incubation, B9 cells $\left(3 \times 10^{3}\right.$ in $\left.0.1 \mathrm{ml}\right)$ were added to each well and incubation was continued for $3 \mathrm{~d} .\left[{ }^{3} \mathrm{H}\right]$ Thymidine was added during the final $18 \mathrm{~h}$ of culture. Results are expressed as mean cpm of triplicate cultures.

much of this bioactivity derived from murine IL-6 in the culture supernatant, because it was largely neutralized by a heteroantiserum to mouse IL-6 (28) and only to a small degree by a MAb to human IL-6 (29). Results for all tumor-conditioned media were similar, and representative neutralizations are shown in Fig. 3, $C$ and $D$. It should be noted that the antiIL-6 reagents were specific for human or mouse IL-6 (Fig. 3, $A$ and $B$ ). Detection of mouse IL-6 in the culture supernatants suggests the presence of reactive mouse cells secreting high levels of IL-6 mixed in with the tumor cells of human origin.

After at least 12 passages in continuous cell culture, all tumor-derived cell lines continued to produce IL-6 bioactivity, in four of eight cases at substantially lower levels ( $\geq 8$-fold) than immediately after transfer to in vitro culture (Table V). In each case, all of this IL- 6 bioactivity was neutralized by a MAb to human IL-6 (29), indicative of its human nature (representative neutralizations are shown in Fig. 3, $E$ and $F$ ). This is likely due to a loss, with passage in culture, of nonproliferating IL-6secreting murine cells, and overgrowth of human IL-6-secreting lymphoblastoid cells. It should be noted that the three cell lines originated from tumor-bearing animals inoculated with the parent cell line VDS-0 and the virus control line VDS-0 1.4 (tVDS-0a, tVDS-0b, and tVDS-0 1.4) produced substantially higher levels of human IL-6 than the lines originally inoculated in the animal (Table II). This finding suggests the occurrence of selection in vivo for high level IL-6-producing clones.

Phenotype of IL-6 virus-infected lymphoblastoid cell lines. In view of the evidence that lymphoblastoid cell lines expressing high levels of IL-6 are more tumorigenic than control lines, it was of interest to know whether these lines might display a Burkitt's lymphoma-like phenotype (37-43). However, all lymphoblastoid cell lines, regardless of how much IL-6 they produced and how tumorigenic they were, expressed similar levels of the B cell activation antigen CD23, and the cell adhesion molecule CD18 ( $\beta$ chain of LFA-1); none expressed CD10 (data not shown). Furthermore, all the IL-6 virus-infected lines grew in tissue culture as large clumps. Together, these data demonstrate that high level IL-6 expression in EBV-immortalized B lymphocytes does not result in their acquisition of a Burkitt's phenotype.

Given that IL- 6 promotes the proliferation of EBV-immortalized cells (16-18), the tumorigenic effect of IL-6 could depend upon IL-6 providing a growth advantage to EBV-immor-

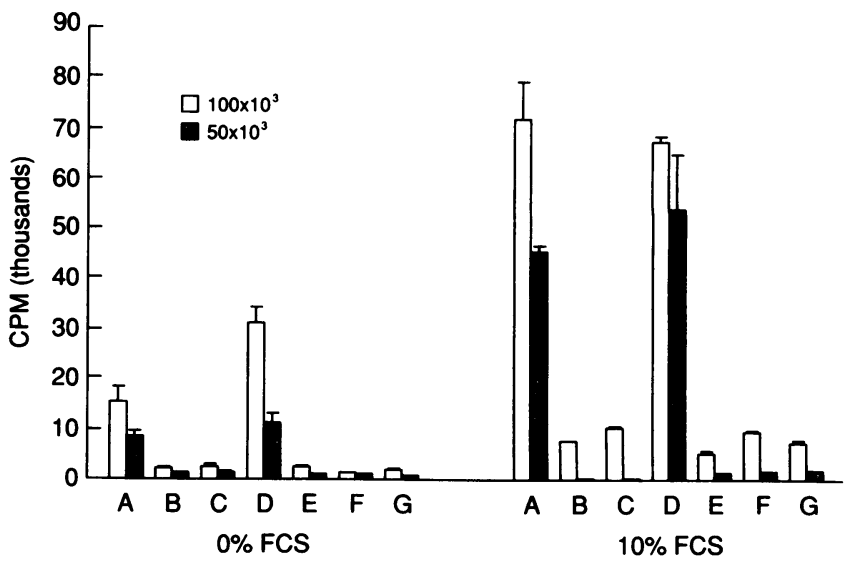

Figure 4. In vitro proliferative responses of parental TB and VDS-0 cell lines and IL-6-expressing TB and VDS-0 clones. TB $(A)$, TB 1 $(B)$, TB $5(C)$, VDS-0 $(D)$, VDS-0 $1(E)$, VDS-0 $2(F)$, and VDS-0 3 $(G)$ lines were cultured at $100 \times 10^{4}$ (open bar) and $50 \times 10^{4}$ (hatched bar) as described in Methods in either Opti-MEM or RPMI supplemented with $10 \%$ FCS. Cell proliferation was measured by $\left[{ }^{3} \mathrm{H}\right]$ thymidine incorporation during the final $4.5 \mathrm{~h}$ of a 3-d incubation. Results are expressed as the mean cpm of triplicate samples \pm SEM. 
talized cells. However, in a series of in vitro studies, all IL-6transfected lines proliferated less vigorously than the parental cell lines either under optimal culture conditions (cell density $1-3 \times 10^{5} / \mathrm{ml}$ and culture medium composed of RPMI with $10 \%$ FCS) or under suboptimal culture conditions, including low cell densities $\left(1-5 \times 10^{4}\right.$ cells $\left./ \mathrm{ml}\right)$ and/or deficient medium (serum-free culture medium, Opti-MEM) (Fig. 4). We examined whether the inhibited growth seen in IL-6 virus-infected lines was due to direct inhibition of B cell growth by IL-6 secreted at high levels. In three separate experiments, IL-6 at doses of $10^{4}, 10^{5}, 10^{6}, 10^{7}$, and $10^{8} \mathrm{U} / \mathrm{ml}$ inhibited the proliferation of VDS- 0 cells $\left(10^{4}\right.$ cells $/ \mathrm{ml}$ in culture medium consisting of RPMI 1640 supplemented with $10 \%$ FCS; $3-d$ culture) by a mean of $38,42,67,78$, and $92 \%$, respectively. It is therefore likely that inhibited growth by IL-6-transfected lymphoblastoid cell lines is due to direct inhibition by IL-6 secreted at high levels in the immediate proximity of the target cells. This finding further suggests that increased tumorigenicity of lymphoblastoid cells secreting high levels of IL-6 is not due to IL-6 providing a growth advantage to the cells secreting it.

Potential mechanisms mediating tumorigenicity of EBVimmortalized $B$ cells. Since the above experiments indicated that tumorigenicity of IL-6-expressing lymphoblastoid lines is not readily explained on the basis of a direct effect of IL- 6 on the B cells, an alternative possibility is that IL-6 might inhibit host immunity. Although immunocompromised, nude mice can produce antibodies to human cell-associated antigens (44), display high level natural killer function (45), and may develop activated monocytes in response to certain tumor cells (46). In vitro, EBV-activated $B$ cells are sensitive to natural killer activity $(47,48)$, and activated monocytes secrete tumoricidal molecules such as tumor necrosis factor (49) and IL-1 (50).

To address the possibility that IL-6 might inhibit host immunity, spleen cells from nude mice were cultured for $4 \mathrm{~d}$ with or without IL-6 $\left(10^{8} \mathrm{U} / \mathrm{ml}\right)$ in the presence of IL-2 $(400 \mathrm{U} / \mathrm{ml})$. As shown in Table VI, IL-2-activated spleen cells killed efficiently both the lymphoblastoid cell line VDS-0 and the NKsensitive YAC cell line. Addition of IL-6 together with IL-2 during preculture resulted in marked reduction of target cell killing at all E/T ratios tested. Because IL-6, at doses of $10^{4}-10^{8}$ $\mathrm{U} / \mathrm{ml}$, had no effect both on VDS-0 and YAC-1 target cell

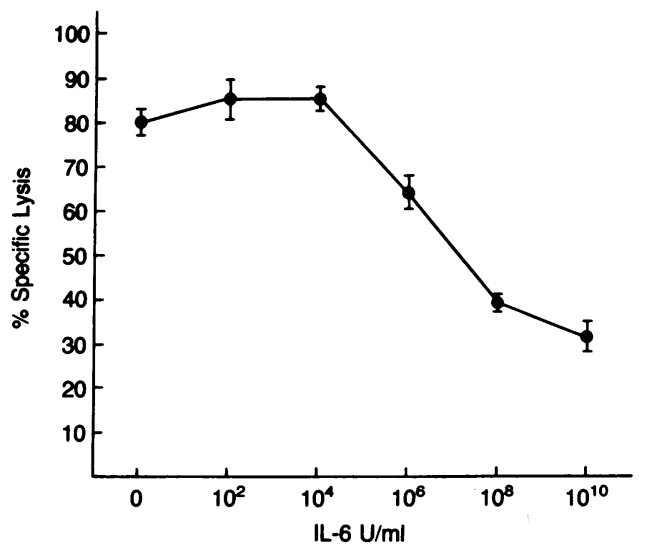

Figure 5. IL-6 inhibition of IL-2-induced killing is dose dependent. Combined splenocytes from three nude mice were preincubated for $4 \mathrm{~d}$ in medium supplemented with either IL-2 alone $(500 \mathrm{U} / \mathrm{ml})$ or with IL-2 plus IL-6 at varying concentrations $\left(10^{2}-10^{10} \mathrm{U} / \mathrm{ml}\right)$. After incubation, the cells were tested in triplicate for cytotoxic activity against ${ }^{51} \mathrm{Cr}$-labeled VDS-0 target cells at a ratio of 100:1. The results are expressed as percent mean specific lysis \pm SD.

killing by cells already activated in vitro with IL-2 (not shown) and on the viability of splenocytes cultured with IL-2, the present experiments demonstrate that IL-6 interferes with IL-2 activation of killer cells but is not cytotoxic for these cells. Effective suppression of IL-2-induced killing required a high cytokine concentration (Fig. 5), $>10^{8} \mathrm{U} / \mathrm{ml}$.

\section{Discussion}

In the present study, we have explored a potential role for IL-6 in B-cell lymphomagenesis. When the IL-6 gene was expressed at high levels in EBV-immortalized normal B lymphocytes these cells became highly tumorigenic in athymic mice. It is unlikely that this effect is the result of a direct action of IL-6 on the B cell because IL-6-expressing lymphoblastoid cell lines were indistinguishable from IL-6 nonexpressing lines in morphology and a number of cell surface characteristics. In addition, the IL-6-expressing cells exhibited no growth advantage

Table VI. IL-6 Inhibits the Activation of IL-2-stimulated Killer Cells

\begin{tabular}{|c|c|c|c|c|c|c|c|c|c|}
\hline \multirow[b]{3}{*}{ Exp. } & \multirow{3}{*}{$\begin{array}{c}\text { Culture } \\
\text { conditions }\end{array}$} & \multicolumn{8}{|c|}{ Percent specific killing } \\
\hline & & \multicolumn{4}{|c|}{ VDS-O Cell Targets } & \multicolumn{4}{|c|}{ YAC Cell Targets } \\
\hline & & 100:1 & $50: 1$ & 25:1 & $12: 1$ & 100:1 & $50: 1$ & $25: 1$ & $12: 1$ \\
\hline \multirow[t]{2}{*}{1} & IL-2 & $81^{\ddagger}$ & 54 & 38 & 20 & 62 & 58 & 48 & 35 \\
\hline & $\mathrm{IL}-2$ + IL-6 & 28 & 26 & 16 & 7 & 40 & 37 & 28 & 26 \\
\hline \multirow[t]{2}{*}{2} & IL-2 & 80 & 60 & 49 & 29 & 97 & 81 & 79 & 72 \\
\hline & $\mathrm{IL}-2$ + IL-6 & 39 & 29 & 5 & 4 & 63 & 61 & 48 & 28 \\
\hline \multirow[t]{3}{*}{3} & IL-2 & 50 & 49 & 33 & 14 & 46 & 44 & 41 & 20 \\
\hline & IL-6 & 2 & 0 & 0 & 0 & 6 & 1 & 0 & 1 \\
\hline & IL-2 + IL-6 & 15 & 14 & 3 & 5 & 28 & 23 & 29 & 16 \\
\hline
\end{tabular}

* Fresh splenocytes from 4-6-wk-old nude mice were incubated $\left(2 \times 10^{6}\right.$ cells $/ \mathrm{ml}, 2 \mathrm{ml} /$ well) with either IL-2 alone (500 U/ml) or IL-6 alone (10 $\mathrm{U} / \mathrm{ml})$ or IL-2 $(500 \mathrm{U} / \mathrm{ml})$ plus IL-6 $\left(10^{8} \mathrm{U} / \mathrm{ml}\right)$ for $4 \mathrm{~d}$ in complete mouse cell culture medium. After incubation, the cells were tested for killing of ${ }^{51} \mathrm{Cr}$-labeled VDS-O or YAC-1 cell targets at the indicated ratios. ${ }^{\ddagger}$ Results of cytotoxicity assays are expressed as mean percent specific lysis of triplicate culture. Standard deviations were within $15 \%$ of the mean. 
in vitro over IL-6 nonexpressing cells. Rather, IL-6-associated tumorigenicity in this experimental system is likely to depend upon IL-6 inhibiting host tumor immunity.

In recent studies, introduction of an IL-6 cDNA expression vector in an EBV-immortalized B cell line conferred the line a growth advantage in culture, and made it tumorigenic in nude mice (51). The growth advantage exhibited by the IL-6-transfected cells was attributed to a direct autocrine action of IL-6 on the B cell. In the experiments described here, the IL-6transfected cells proliferated less vigorously than control cells under a variety of culture conditions. The different results are likely to depend upon the different amounts of IL-6 secreted by the two sets of transfectants. The IL- 6 virus-infected cell lines used here produced between 6,500 and 40,000 IL- 6 units per milliliter of culture conditioned by $10^{6}$ cells for $48 \mathrm{~h}$ (Table I). In contrast, the IL-6-transfected MC3 cells appeared to produce levels of IL-6 lower by at least 20 -fold. We have previously reported that IL-6 can stimulate growth in EBV-infected B cells at concentrations of $10-100 \mathrm{U} / \mathrm{ml}(16-18)$. However, at concentrations greater than $5,000 \mathrm{U} / \mathrm{ml}, \mathrm{IL}-6$ was found to inhibit growth in EBV-immortalized B cells in a dose-dependent manner. Thus, similar to other cytokines, IL- 6 may exhibit both stimulatory and inhibitory effects on the same target cells depending upon its concentration.

Since all five IL-6-expressing lines used here exhibited decreased proliferation in vitro when compared with control lines, it is unlikely that increased tumorigenicity is the result of direct B cell stimulation by IL-6. Rather, tumorigenicity may lie upon an IL-6-mediated impairment of tumor cell surveillance. Although immunocompromised, nude mice display high levels of natural killer functions (45), and in vitro, EBVactivated B cells are sensitive to NK activity $(47,48)$.

Results presented here indicate that IL-6, at high concentrations, inhibits lymphokine-activated killer (LAK) activity by nude mouse splenocytes. LAK cells are believed to derive, for the most part, from lymphokine activation of NK cells (52). Consistent with these results in vitro, the increased tumorigenicity of IL-6-expressing lymphoblastoid cell lines in vivo might depend upon IL-6 inhibiting NK functions at the tumor site. In the human, NK cells are activated by IL-6 at low concentrations $(\leq 1 \mathrm{U} / \mathrm{ml})$, indicating that these cells express functional IL-6 receptors (53). At high concentrations, IL-6 might downregulate IL-6 receptor expression, a process reported to occur in monocytes (54).

In addition to displaying high levels of NK activity, nude mice may develop activated monocytes in response to certain tumor cells (46). Monocyte activation at the tumor site was prominent in this study, as evidenced by the high levels of murine IL- 6 produced by tumor cell suspensions cultured in vitro. When activated, monocytes may secrete tumoricidal molecules such as tumor necrosis factor (49) and IL-1 (50). Recently, it was reported that IL- 6 can downregulate IL- $1 \beta$ and TNF gene expression in human activated monocytes by acting at the level of transcription (55). If tumor-derived IL-6 is capable of similar actions in vivo, it could effectively inhibit a potentially important cytocidal function of the monocyte at the tumor site.

Polyclonal and oligoclonal malignancies of EBV-infected B lymphocytes have been reported with increasing frequency in individuals with acquired immunodeficiencies such as AIDS patients $(2,56)$ and post-transplant recipients $(4)$. The observation that EBV-immortalized B cells secreting high levels of IL-6 have a propensity for giving rise to tumors in immunocompromised hosts raises the possibility that IL- 6 may be a factor in human B cell lymphomagenesis. It is worth noting that HIV-1infected individuals generally display abnormally elevated serum IL-6 levels $(57,58)$, possibly through a direct action of the virus $(58,59)$. This abnormality could predispose AIDS patients to the development of EBV-associated malignancies.

Recently, IL- 6 has been considered for experimental therapy in cancer patients. The results presented here suggest that this molecule should be used with caution.

\section{Acknowledgments}

We thank Dr. E. Jaffe for examining tumor cell biopsies; the NIH Blood Bank for continuous support; Dr. P. B. Sehgal for providing the cDNA clone pBeta-2-22; Dr. R. Nordan for providing the hybridoma B9 cell line, mouse IL-6, and an anti-murine IL-6 antibody; Dr. M. Aarden for providing a MAb to human IL-6; and Dr. McManaway for helping with animal experiments. We also thank Dr. I. T. Magrath for helpful discussions; Drs. R. Yarchoan and L. Matis for critically reading the manuscript; and Ms. E. Caruso for editorial assistance.

\section{References}

1. Purtilo, D. T. 1977. Opportunistic non-Hodgkin's lymphoma in X-linked recessive immunodeficiency and lymphoproliferative syndromes. Serum Oncol. 4:335-341.

2. Ziegler, J. L., J. A. Beckstead, P. A. Volberding, D. I. Abrams, A. M. Levine, R. J. Lukes, P. S. Gill, R. L. Burkes, P. R. Meyer, C. E. Metroka, et al. 1984. Non-Hodgkin's lymphoma in 90 homosexual men. Relation to generalized lymphadenopathy and acquired immunodeficiency syndrome. N. Engl. J. Med. 311:565-570.

3. Pelicci, P. G. D. M. Knowles, Z. A. Arlin, R. Wieczorek, P. Luciw, D. Dina, C. Basilico, and R. Dalla-Favera. 1966. Multiple monoclonal B-cell expansion and c-myc oncogene rearrangements in acquired immune deficiency syndrome related lymphoproliferative disorders. Implications for lymphomagenesis. J. Exp. Med. 164:2049-2060.

4. Ho, M., R. Jaffe, G. Miller, M. K. Breinig, J. S. Dummer, L. Makowka, R. W. Atchinson, F. Kaner, M. A. Nalesnik, and T. S. Starzl. 1988. The frequency of Epstein-Barr virus infection and associated lymphoproliferative syndrome after transplantation and its manifestations in children. Transplantation (Baltimore). 45:719-727.

5. Klein, G. and E. Klein. 1985. Evolution of tumors and the impact of molecular oncology. Nature (Lond.). 315:190-195.

6. Klein, G. 1989. Viral latency and transformation: the strategy of EpsteinBarr virus. Cell. 58:5-8.

7. Tosato, G. The Epstein-Barr virus and the immune system. 1987. $A d v$. Cancer Res. 49:75-125.

8. Van Snick, J. 1990. Interleukin-6: an overview. Annu. Rev. Immunol. 8:253-278.

9. Miles, S. A., A. R. Rezai, J. F. Salazar-Golzalez, M. Vander Meyden, R. H. Stevens, D. M. Logan, R. T. Mitsuyama, T. Taga, T. Hirano, T. Kishimoto, and O. Martinez-Maza. 1990. AIDS Kaposi sarcoma-derived cells produce and respond to interleukin 6. Proc. Natl. Acad. Sci. USA 87:4068-4072.

10. Hirano, T., T. Taga, K. Yasukawa, K. Nakajima, N. Nakano, F. Takatsuki, M. Shimuzu, A. Marashima, S. Tsunasawa, F. Sakiyama, and T. Kishimoto. 1987. Human B cell differentiation factor defined by an anti-peptide antibody and its possible role in autoantibody production. Proc. Natl. Acad. Sci. USA. 84:228-231.

11. Yoshizaki, K., T. Matsuda, N. Nishimoto, T. Kuritani, T. Taeho, K. Aozasa, T. Nakahata, H. Kawai, H. Togoh, T. Komori, S. Kishimoto, T. Hirano, and T. Kishimoto. 1989. Pathogenic significance of interleukin-6 (IL-6/BSF-2) in Castleman's disease. Blood. 74:1360-1367.

12. Kawano, M., T. Hirano, T. Matsuda, T. Taga, Y. Horii, K. Iwato, H. Asaoku, B. Tang, O. Tanabe, H. Tanaka, A. Kuramoto, and T. Kishimoto. 1988. Autocrine generation and requirement of BSF-2/IL-6 for human multiple myelomas. Nature (Lond.). 332:83-85.

13. Klein, B., X.-G. Zhang, M. Jourdan, J. Content, F. Houssiaue, L. Aarden, M. Piechaczyk, and R. Bataille. 1989. Paracrine rather than autocrine regulation of myeloma cell growth and differentiation by interleukin 6. Blood. 73:517-526.

14. Freeman, G. J., A. S. Freedman, S. N. Rabinowe, J. M. Segil, J. Horowitz, K. Rosen, J. F. Whitman, and L. M. Nadler. 1989. Interleukin-6 gene expression in normal and neoplastic B cells. J. Clin. Invest. 82:1512-1518.

15. Biondi, A., R. R. Bassan, T. Barbui, S. Bettoni, M. Sironi, A. Mantovani, 
and A. Rambaldi. 1989. Constitutive expression of the interleukin-6 gene in chronic lymphocytic leukemia. Blood. 73:1279-1284.

16. Tosato, G., K. B. Seamon, N. D. Goldman, P. B. Sehgal, L. T. May, G. C Washington, K. D. Jones, and S. E. Pike. 1988a. Identification of a monocytederived human B cell growth factor as interferon- $\beta_{2}$ (BSF-2, IL-6). Science (Wash. DC). 239:502-504.

17. Tosato, G., T. L. Gerrard, N. D. Goldman, and S. E. Pike. 1988. Stimulation of EBV-activated human B cells by monocytes and monocyte products. Role of IFN- $\beta_{2} / B$ cell stimulating factor 2/IL-6. J. Immunol. 140:4329-4336.

18. Tosato, G., G. Tanner, K. D. Jones, M. Revel, and S. E. Pike. 1990 Identification of interleukin- 6 as an autocrine growth factor for Epstein-Bar virus-immortalized B cells. J. Virol. 64:3033-3047.

9. Taga, T., K. Kawaniski, R. R. Hardy, T. Hirano, and T. Kishimoto. 1987. Receptors for B cell stimulatory factor 2. Quantitation, specificity, distribution and regulation of their expression. J. Exp. Med. 166:967-981.

20. Mule, J. J., J. K. McIntosh, D. M. Jablongs, and S. A. Rosenberg. 1990 Antitumor activity of recombinant interleukin-6 in mice. J. Exp. Med. 171:629636.

21. May, L. T., D. C. Helfgott, and P. B. Sehgal. 1986. Anti- $\beta$ interferon antibodies inhibit the increased expression of HLA-B7 in RNA in tumor necrosis factor-treated human fibroblasts: structural studies of the $\beta 2$. Proc. Natl. Acad. Sci. USA. 83:8957-8961.

22. Cepko, C. L., B. Roberts, and R. C. Mulligan. 1984. Construction and applications of a highly transmissable murine retrovirus shuttle vector. Cell. 37:1053-1062.

23. Cone, R. D., and R. C. Mulligan. 1984. High efficiency gene transfer into mammalian cells. Generation of helper-free recombinant retrovirus with broad mammalian host range. Proc. Natl. Acad. Sci. USA. 81:6349-6353.

24. Miller, A. D., and C. Buttimore. 1986. Redesign of retrovirus packaging cell lines to avoid recombination leading to helper virus production. Mol. Cell. Biol. 6:2895-2902.

25. Aarden, L. A., E. R. DeGroot, D. L. Schaap, and P. M. Lansdorp. 1987 Production of hybridoma growth factor by human monocytes. Eur. J. Immunol. 17:1411-1416

26. Tanner, J. E., N. D. Goldman, and G. Tosato. Biochemical and biological analysis of the human interleukin 6 expressed in rodent and primate cells. Cytokine. 2:363-374

27. Laemmli, U. K. 1970. Cleavage of structural proteins during the assembly of the head of bacteriophage T4. Nature (Lond.). 227:680-000.

28. Hilbert, D. M., M. P. Cancro, P. A. Scherle, R. P. Nordan, J. Van Snick, W. Gerhard, and S. Rudikoff. 1989. T cell derived IL-6 is differentially required for antigen-specific antibody secretion by primary and secondary B cells. J. Immunol. 143:4019-4024.

29. Brakenhott, J. P., M. Hart, E. R. De Groot, F. Di Padova, and L. A. Aarden. 1990. Structure function analysis of human IL-6. Epitope mapping of neutralizing monoclonal antibodies with amino- and carboxyl-terminal deletion mutants. J. Immunol. 145:561-568.

30. Nordan, R. P., J. G. Pumphrey, and S. Rudikoff. 1987. Purification and $\mathrm{NH}_{2}$-terminal sequence of a plasmacytoma growth factor derived from the murine macrophage cell line P388D1. J. Immunol. 139:813-817.

31. Tepper, R. I., P. K. Pattengale, and P. Leder. 1989. Murine interleukin-4 displays potent antitumor activity in vivo. Cell. 571:503-512.

32. Terasaki, P. I. and J. D. McClelland. 1964. Microdroplet assay of human serum cytotoxins. Nature (Lond.). 204:998-1001.

33. Wang, F., R. M. Blaese, K. C. Zoon, and G. Tosato. 1987. Suppression T cell clones from patients with acute Epstein-Barr virus-induced infectious mononucleosis. $J$. Clin. Invest. 79:1-8.

34. Tosato, G., G. E. Marti, R. Yarchoan, C. A. Heilman, F. Wang, S. E. Pike, S. J. Korsmeyer, and K. Siminovitch. 1986. Epstein-Barr virus immortalization of normal cells of B cell lineage with nonproductive, rearranged immunoglobulin genes. J. Immunol. 137:12037-12042.

35. Nilsson, K., B. C. Giovanella, J. S. Stehlin, and G. Klein. 1977. Tumorigenicity of human hematopoietic cell lines in athymic nude mice. Int. J. Cancer 19:337-344.

36. Busuttil, A., G. T. O'Connor, M. E. Foster, V. Gurtsevitch, J. E. M. Morten, and C. M. Steel. 1986. The gross pathology and histological features of tumors produced by inoculation of human cell lines into immune-deprived mice. J. Pathol. 148:561-568.

37. Nilsson, K., and G. Klein. 1982. Phenotypic and cytogenetic characteristics of human B lymphoid cell lines and their relevance for the etiology of Burkitt's lymphoma. Adv. Cancer Res. 37:319-380.

38. Rowe, M., C. M. Rooney, C. F. Edwards, G. M. Lenoir, and A. B. Rickinson. 1985. Epstein-Barr virus status and tumor cell phenotype in sporadic Burkitt's lymphoma. Int. J. Cancer. 37:367-373.
39. Rowe, M., D. T. Rose, C. D. Gregory, L. S. Young, P. J. Farrell, H. Rupani, and A. B. Rickinson. 1987. Differences in B cell growth phenotype reflect novel patterns of Epstein-Barr virus latent gene expression in Burkitt's lymphoma cells. EMBO (Eur. Mol. Biol. Organ.) J. 6:2743-2751.

40. Ehlin-Hendriksson, B., A. Manneborg-Sondlund, and G. Klein. 1987. Expression of B-cell specific markers in different Burkitt lymphoma subgroups. Int. J. Cancer 39:211-218.

41. Rooney, C. M., C. D. Gregory, M. Rowe, S. Finerty, C. Edwards, H. Rupani, and A. B. Rickinson. 1986. Endemic Burkitt's lymphoma: phenotypic analysis of tumor biopsy cells and of derived tumor cell lines. J. Natl. Cancer Inst. 77:681-687.

42. Gregory, C. D., R. J. Murray, C. F. Edwards, and A. B. Rickinson. 1988. Downregulation of cell adhesion molecules LFA-3 and ICAM-1 in Epstein-Barr virus-positive Burkitt's lymphoma underlies tumor cell escape from virus-specific T cell surveillance. J. Exp. Med. 167:1811-1824.

43. Patarroyo, M., J. Prieto, I. Ernberg, and C. G. Gahmberg. 1988. Absence, or low expression of leukocyte-adhesion molecules CD11 and CD18 on Burkitt's lymphoma cells. Int. J. Cancer. 41:901-907.

44. Povlsen, C. O., P. J. Fialkow, E. Klein, G. Klein, J. Rygaard, and F. Wiener. 1973. Growth and antigenic properties of a biopsy-derived Burkitt's lymphoma in thymus-less (nude) mice. Int. J. Cancer 11:30-39.

45. Kiessling, R., G. Klein, H. Pross, and H. Wigzell. 1975. Natural killer cells in the mouse. II. Cytotoxic cells with specificity for mouse Moloney leukemia cells. Characteristics of the killer cells. Eur. J. Immunol. 5:117-121.

46. Jacubovich, R., H. Cabrillat, D. Gerlier, M. Bailly, and J. F. Dore. 1985. Tumorigenic phenotypes of human melanoma cell lines in nude mice determined by an active antitumor mechanism. Br. J. Cancer 51:335-345.

47. McCormick, K. J., B. C. Giovannella, G. Klein, K. Nilsson, and J. S. Stehlin. 1981. Diploid human lymphoblastoid and Burkitt's lymphoma cell lines: susceptibility to murine NK cells and heterotransplantation to nude mice. Int. J. Cancer. 28:455-458.

48. Masucci, M. G., M. T. Bejarano, G. Masucci, and E. Klein. 1983. Large granular lymphocytes inhibit the in vitro growth of autologous Epstein-Barr virus-infected B cells. Cell. Immunol. 76:311-321.

49. Urban, J. L., H. M. Shepard, J. L. Rotstein, B. J. Sugarman, and H. Schreiber. 1986. Tumor necrosis factor: a potent effector molecule for tumor cel killing by activated macrophages. Proc. Natl. Acad. Sci. USA. 83:5233-5237.

50. Onozaki, K., K. Matsushima, B. B. Aggarwal, and J. J. Oppenheim. 1985 Human interleukin-1 is a cytocidal factor for several tumor cell lines. J. Immunol. 135:3962-3968.

51. Scala, G., I. Quinto, M. R. Ruocco, A. Arcucci, M. Mallardo, P. Caretto, G. Forni, and S. Venuta. 1990. Expression of an exogenous interleukin-6 gene in human Epstein-Barr virus $B$ cells confers growth advantage and in vivo tumorigenicity. J. Exp. Med. 172:61-68.

52. Reynolds, C. W., and J. R. Rotaldo. 1990. Nature and physiology of natural effector cells. In Immunopathology. J. Oppenheim and E. Shevach, editors. Oxford University Press, New York. 336-349.

53. Luger, T. A., J. Krutmann, R. Kirnbauer, A. Rubanski, T. Schwarz, G Klappacher, A. Kock, M. Micksche, J. Malijczyk, E. Schauer, L. T. May, and P. B. Sehgal. 1989. IFN $\beta_{2} /$ IL-6 augments the activity of human natural killer cells. J. Immunol. 143:1206-1209.

54. Bauer, J., T. M. Bauer, T. Kalb, T. Taga, G. Lengyel, T. Hirano, T. Kishimoto, G. Acs, L. Mayer, and W. Gerok. 1989. Replication of interleukin 6 receptor expression in human monocytes and monocyte-derived macrophages. $J$. Exp. Med. 170:1537-1549.

55. Schindler, R, J. Mancilla, S. Endres, R. Ghorbani, S. C. Clark, and C. A. Dinarello. 1990. Correlations and interactions in the production of interleukin 6 (IL-6), IL-1, and tumor necrosis factor (TNF) in human blood mononuclear cells: IL-6 suppresses IL-1 and TNF. Blood. 75:40-47.

56. Pluda, J. M. R. Yarchoan, E. S. Jaffe, I M. Feuerstein, D. Solomon, S. M. Steinberg, K. M. Wyrill, A. Raubitschek, D. Katz, and S. Broder. 1990. Development of non-Hodgkin's lymphoma in a cohort of patients with severe human immunodeficiency virus (HIV) infection on long-term antiretroviral therapy. Ann. Int. Med. 113:276-282.

57. Breen, E. C., A. R. Rezai, K. Nakajima, G. N. Beall, R. T. Mitsuyasu, T. Hirano, T. Kishimoto, and O. Martinez-Maza. 1990. Infection with HIV is associated with elevated IL-6 levels and production. J. Immunol. 144:480-484.

58. Birx, D., R. R. Redfield, K. Tencer, A. Fowler, D. S. Burke, and G. Tosato. 1990. Induction of interleukin 6 during human immunodeficiency virus infection. Blood. 76:2302-2310.

59. Nakajima, T. O. Martinez-Maza, T. Hirano, E. C. Breen, P. G. Nishanian, J. F. Salazar-Gonzales, J. L. Fahey, and T. Koshimoto. 1978. Induction of IL-6 (B-cell stimulatory factor $2 /$ INF $\beta 2$ ) production by HIV. J. Immunol. 142:531-536. 